\title{
EFEKTIFITAS MODEL PEMBELAJARAN JIGSAW II PADA MATERI BARISAN DAN DERET DITINJAU DARI TIPE KEPRIBADIAN SISWA KELAS X SMK MUHAMMADIYAH 3 KLATEN UTARA
}

\author{
Aji Permana Putra \\ Universitas Cokroaminoto Yogyakarta
}

\begin{abstract}
The objectives of this research were to find out on the topic of Sequences and Series: (1) which had better learning achievement among cooperative learning Group Jigsaw II or a direct learning; (2) which had better learning achievement between melancholies students, phlegmatic students, sanguine students or choleric students; (3) at each personality types, which had better learning achievement among Jigsaw II or direct learning, and (4) at each learning models, which had better learning achievement between melancholies students, phlegmatic students, sanguine students or choleric students. This research was a quasi-experimental with $2 \times 4$ factorial design. The population was all students of SMK Muhammadiyah 3 Klaten Utara on Academic Years 2019/2020. Sampling was done by stratified cluster random sampling technique. The total of sample was 85 students. Statistical tests using the method Lilliefors test for normality, homogeniety of the Bartlett method, anava test with $\mathrm{F}$ test (Fisher) and post hoc test using the Scheffe' method. The significance level was 0,05. Based on hypothesis test, it could be concluded as follows: (1) Jigsaw II had better learning achievement than direct learning,; (2) there were no any differences in the learning achievement in mathematics of the students with melancholies, phlegmatic, sanguine or choleric personality types; (3) in each personality types, the cooperative learning model Jigsaw II had better than direct learning model; (4) in each learning model, the students with melancholies, phlegmatic, sanguine or choleric personality types have the same learning achievement.
\end{abstract}

Keywords: Melancholies, Choleric, Phlegmatic, Sanguine, Jigsaw II and Direct learning.

\section{PENDAHULUAN}

Sebagai bangsa yang besar, Indonesia selalu berusaha memajukan kualitas sumber daya manusianya, salah satunya yaitu dengan meningkatkan mutu pendidikan. Peningkatan mutu pendidikan dapat dilihat dari prestasi yang diperoleh siswa baik tingkat local maupun nasional. Pada kenyataannya terdapat banyak masalah-masalah yang mengakibatkan mutu pendidikan di Indonesia masih rendah.

Masalah pendidikan yang dihadapi salah satunya adalah pembelajaran matematika, yaitu penguasaan mata pelajaran matematika yang masih rendah. Rendahnya penguasaan matematika siswa tercermin dalam rendahnya prestasi siswa Indonesia baik di tingkat internasional maupun di tingkat nasional. Berdasarkan rangking Trends International Mathematics and Sciences Study (TIMSS) 2003, Indonesia menduduki posisi 36 dari 45 peserta. Pada TIMSS tahun 2007, Indonesia turun ke posisi 41 dari 48 peserta. Sedangkan untuk penilaian Programme for International Student Assesment (PISA) yang dipublikasikan OECD (Organization for Economic Cooperation and Development) dalam Ariadi Wijaya (2012), tahun 2006 Indonesia menempati posisi 50 dari 57 negara dan pada PISA 2009, 
Indonesia turun ke posisi 61 dari 65 negara. Pada PISA 2012 Indonesia berada pada peringkat 64 dari 65 negara dengan skor rata-rata 375, padahal skor rata-rata OECD 494 (OECD, 2014).

Hasil Ujian Nasional pada jenjang SMK 2018/ 2019 nilai terendah pada pelajaran Matematika 0,25, diikuti Bahasa Indonesia 0,60, kemudian Bahasa Inggris 1,00 dan Kompetensi Keahlian 1,57 (PAMER UN BALITBANG KEMDIKBUD). Rendahnya nilai Matematika memang merata di seluruh Indonesia tak terkecuali di Kabupaten Klaten. Hasil Ujian Nasional SMK Kabupaten Klaten tahun pelajaran 2018/ 2019 nilai tertinggi Matematika dengan nilai 10,00 tetapi nilai terendah 0,75 juga jatuh pada mata pelajaran Matematika.

Dilihat dari daya serap UN 2018/2019 mata pelajaran Matematika, kompetensi dasar menyelesaikan masalah yang berkaitan dengan barisan atau deret aritmatika daya serapnya 63,40\%, lebih rendah daripada kompetensi dasar menentukan integral tak tentu atau integral tentu dari fungsi aljabar atau fungsi trigonometri 78,52\% yang baru dipelajari pada jenjang SMK. Selain itu daya serap materi barisan dan deret di Kabupaten Klaten, lebih rendah dari daya serap di provinsi maupun nasional, seperti disajikan tabel berikut:

Tabel 1. Daya serap materi Barisan dan Deret SMK Tahun Ajaran $2018 / 2019$

\begin{tabular}{lccc}
\hline \multirow{2}{*}{ Kompetensi Dasar } & \multicolumn{3}{c}{ Daya Serap (\%) } \\
\cline { 2 - 4 } & Kab & Prop & Nas \\
\hline $\begin{array}{l}\text { Mengidentifikasi pola, barisan, atau deret } \\
\text { bilangan. }\end{array}$ & 76,35 & 83,43 & 84,42 \\
\hline $\begin{array}{l}\text { Menyelesaikan masalah yang berkaitan } \\
\text { dengan barisan atau deret aritmatika. }\end{array}$ & 62,50 & 64,43 & 75,36 \\
\hline
\end{tabular}

Sumber : Balitbang Kemdikbud 2019

Rendahnya prestasi belajar matematika menuntut adanya perubahan dalam proses pembelajaran, salah satunya model pembelajaran. Berdasarkan penelitian di salah satu SMK di Klaten, pembelajaran matematika yang dilaksanakan menggunakan model pembelajaran langsung, dimana guru menjelaskan konsep dengan metode ceramah, sedangkan siswa hanya mendengarkan. Dalam pembelajaran ini guru yang berperan aktif sedangkan siswa pasif, bahkan terkadang guru tidak mengetahui apakah siswa sudah paham atau belum dengan materi yang diterangkan. Konsep model pembelajaran langsung secara garis besar situasi pembelajaran didominasi oleh guru. Dimana guru aktif memberikan informasi kepada siswa, sedangkan siswa mendengarkan, mencatat dan mengerjakan tugas yang diberikan, sehingga tidak ada interaksi antar siswa dalam pembelajaran langsung.

Salah satu upaya untuk meningkatkan prestasi belajar siswa dan mutu pendidikan adalah menerapkan model pembelajaran yang inovatif. Dengan model pembelajaran yang inovatif 
diharapkan pembelajaran matematika tidak membosankan, melibatkan peran aktif siswa, menciptakan suasana yang menyenangkan serta adanya interaksi antar siswa dalam pembelajaran. Model pembelajaran yang menuntut siswa aktif dalam bentuk kelompok adalah model pembelajaran kooperatif atau cooperative learning. Cooperative learning adalah model pembelajaran yang menitik beratkan kerjasama dan saling membantu dalam kelompok kecil, umumnya terdiri dari 4 siswa dengan kemampuan yang berbeda (Miftahul Huda, 2013). Cooperative learning adalah pembelajaran yang baik untuk pembelajaran matematika bagi siswa dengan berbagai keadaan (Rivera, 1996). Selain itu Zakaria and Zanaton (2007) menyatakan penggunaan model pembelajaran cooperative pada matematika dan ilmu sains sangat efektif.

Dalam penelitian ini model pembelajaran kooperatif yang dipilih adalah Student Team Learning, karena ada tiga konsep yang mendasari model Student Team Learning, yaitu: penghargaan kelompok (team reward), tanggung jawab individu (individual accountability) dan kesempatan yang sama untuk sukses (equal opportunities for success). Dari ketiga tipe dalam model Student Team Learning akan dipilih Jigsaw II.

Prestasi belajar matematika siswa selain dipengaruhi oleh metode pembelajaran juga dipengaruhi oleh kemampuan siswa dalam menyelesaikan masalah matematika (Karaoglan, 2009). Sedangkan kemampuan siswa dalam menyelesaikan masalah matematika dipengaruhi oleh karakteristik siswa (Pimta et all, 2009). Karakteristik siswa dalam hal ini dapat dikatakan kepribadian. Masing-masing siswa memiliki tipe kepribadian yang berbeda, begitu juga pada siswa SMK. Pada siswa SMK sudah terlihat kepribadian dominan yang dimiliki sehingga dapat ditentukan tipe kepribadian masing-masing siswa.

Litteaur (2011) membagi tipe kepribadian menjadi 4 yaitu melankolis, koleris, phlegmatis dan sanguinis. Keempat tipe kepribadian tersebut mempunyai sifat yang berbeda-beda, siswa yang mempunyai tipe melankolis merupakan pribadi yang tekun, tipe koleris merupakan pribadi yang percaya diri dan mudah mengemukakan pendapat, tipe phlegmatis merupakan pribadi yang sabar dan pendengar yang baik, sedangkan tipe sanguinis merupakan pribadi yang suka berbicara, selalu gembira tetapi kurang berkonsentrasi dan disiplin.

Berdasarkan uraian tersebut penelitian ini bertujuan untuk mengetahui pada materi barisan dan deret: (1) manakah yang memberikan prestasi belajar matematika yang lebih baik antara penggunaan model Jigsaw II atau model pembelajaran langsung, (2) manakah yang mempunyai prestasi belajar yang lebih baik antara siswa dengan tipe kepribadian melankolis, koleris, phlegmatis atau sanguinis, (3) pada masing-masing tipe kepribadian (melankolis, koleris, phlegmatis dan sanguinis) manakah prestasi belajar matematika siswa yang lebih baik antara menggunakan model cooperative learning tipe Jigsaw II atau model pembelajaran langsung, (4) pada masing-masing model pembelajaran (Jigsaw II dan langsung), manakah prestasi belajar matematika siswa yang lebih baik antara siswa dengan tipe kepribadian melankolis, koleris, phlegmatis atau sanguinis. 


\section{METODE PENELITIAN}

Penelitian ini merupakan penelitian eksperimental semu dengan desain faktorial $2 \times 4$. Populasinya adalah seluruh siswa kelas X SMK Muhammadiyah 3 Klaten Utara. Sampel penelitian terdiri dari 85 siswa. Pada penelitian ini pengumpulan data menggunakan metode tes untuk prestasi belajar matematika siswa dan tipe kepribadian siswa. Data kemampuan awal diperoleh dari dokumen nilai ulangan harian materi logika tahun pelajaran 2019/2020. Data ini digunakan untuk menguji keseimbangan rerata populasi kelas eksperimen dan kelas kontrol.

Data prestasi belajar diperoleh melalui tes prestasi belajar matematika pada materi barian dan deret. Soal tes yang digunakan berbentuk pilihan ganda, setiap butir soal mempunyai lima alternatif jawaban. Jawaban yang benar memperoleh skor 1 dan jawaban yang salah memperoleh skor 0 . Validitas instrumen tes prestasi belajar dalam penelitian ini menggunakan validitas isi. Untuk mengetahui daya beda suatu butir soal digunakan rumus korelasi momen produk Karl Pearson. Tingkat kesukaran soal dihitung dengan perbandingan antara subjek yang menjawab benar dengan banyak seluruh subjek. Sedang reliabilitas instrumen tes dihitung menggunakan rumus Kuder dan Richardson. Dari hasil uji coba 60 butir soal terdapat 30 soal yang memenuhi kriteria yang selanjutnya digunakan untuk tes prestasi belajar.

Data tipe kepribadian siswa diperoleh melalui tes dengan instrumen yang diambil dari buku Personality Plus karangan Florence Litteaur. Hal ini dikarenakan instrumen tipe kepribadian merupakan instrumen baku. Validasi yang dilakukan hanya mengacu pada kesesuaian bahasa saja.

Uji keseimbangan dilakukan dengan menggunakan anava satu jalan dengan sel tak sama yang sebelumnya telah dilakukan uji prasyarat. Uji prasyarat meliputi uji normalitas dengan metode Lilliefors dan uji homogenitas variansi dengan metode Bartlett. Uji hipotesis penelitian dilakukan dengan menggunakan analisis variansi satu jalan dengan sel tak sama.

\section{HASIL PENELITIAN DAN PEMBAHASAN}

Sebelum penelitian dilakukan, terlebih dahulu dilakukan uji normalitas dan homogenitas terhadap data kemampuan awal. Dari hasil uji prasyarat tersebut didapat bahwa sampel berasal dari populasi berdistribusi normal dan variansi-variansi populasi homogen. Hasil uji keseimbangan menggunakan analisis variansi satu jalan dengan sel tak sama diperoleh $F_{\text {obs }}=3.09$ dan $F_{0,05 ; 2 ; 83}=3.11$. Dengan memperhatikan $D K=\{F \mid F>3.0351\}$ maka $F_{o b s} \notin D K$ sehingga $H_{0}$ diterima. Hal ini berarti bahwa sampel eksperimen dan kontrol berasal dari populasi yang mempunyai kemampuan awal sama. Tes prestasi diberikan kepada siswa setelah mendapat perlakuan sebagaimana disebutkan sebelumnya. Selanjutnya hasil tes prestasi digunakan untuk 
uji hipotesis yang sebelumnya telah dilakukan uji prasyarat. Uji prasyarat meliputi uji normalitas dan homogenitas terhadap data tes prestasi pada sampel model pembelajaran dan tipe kepribadian siswa. Berdasarkan uji prasyarat didapat bahwa sampel berasal dari populasi berdistribusi normal dan variansi-variansi populasi homogen. Hasil uji hipotesis terangkum dalam Tabel 2 berikut.

Tabel 2. Rangkuman Analisis Variansi Dua Jalan Sel Tak Sama

\begin{tabular}{|c|c|c|c|c|c|c|}
\hline Sumber & $J K$ & $d k$ & $R K$ & $F_{o b s}$ & $F_{\text {tab }}$ & Keputusan \\
\hline Model Pembelajaran (A) & 9972,9171 & 1 & 4986,4586 & 15,7978 & 3,0357 & $H_{0_{A}}$ ditolak \\
\hline Tipe Kepribadian (B) & 549,2522 & 3 & 183,0841 & 0,5800 & 2,432 & $H_{0_{B}}$ diterima \\
\hline Interaksi $\quad(A B)$ & 2822,5927 & 3 & 470,4321 & 1,4904 & 2,235 & $H_{0 A B}$ diterima \\
\hline
\end{tabular}

Berdasar Tabel 2, $H_{0_{A}}$ ditolak. Karena model pembelajaran terdiri atas dua kategori maka tinggal melihat rata-rata prestasi belajar yang diperoleh. Adapun rerata masing-masing kategori dapat dilihat pada Tabel 3.

Tabel 3. Data Rerata Tes Prestasi Belajar

\begin{tabular}{|c|c|c|c|c|c|}
\hline \multirow{2}{*}{$\begin{array}{c}\text { Model } \\
\text { Pembelajaran } \\
\text { (A) }\end{array}$} & \multicolumn{4}{|c|}{ Tipe kepribadian (B) } & \multirow{2}{*}{$\begin{array}{c}\text { Rerata } \\
\text { Margina }\end{array}$} \\
\hline & $\operatorname{Mel}\left(\mathrm{b}_{1}\right)$ & $\operatorname{Kol}\left(\mathrm{b}_{2}\right)$ & Phleg $\left(\mathrm{b}_{3}\right)$ & $\operatorname{Sang}\left(\mathrm{b}_{4}\right)$ & \\
\hline Jigsaw II $\quad\left(a_{1}\right)$ & 80,7857 & 81,3259 & 72,4400 & 75,2333 & 76,5349 \\
\hline Langsung $\left(a_{3}\right)$ & 59,1875 & 56,8182 & 65,6364 & 61,5455 & 59,9333 \\
\hline Rerata marginal & 68,4182 & 68,0167 & 67,0612 & 71,1618 & \\
\hline
\end{tabular}

$H_{0_{A}}$ ditolak, yang berarti bahwa model pembelajaran Jigsaw II dan model pembelajaran langsung memberikan pengaruh yang berbeda terhadap prestasi belajar siswa. Selanjutnya dengan membandingkan rerata marginal prestasi belajar siswa yang dikenai model pembelajaran Jigswa II yaitu 76,5349 dan rerata marginal prestasi belajar siswa yang dikenai model pembelajaran langsung 59,9333 diperoleh kesimpulan bahwa model pembelajaran Jigsaw II memberikan prestasi belajar matematika lebih baik dibanding model pembelajaran langsung.

Faktor yang mempengaruhi hipotesis model pembelajaran kooperatif tipe Jigsaw II lebih baik daripada prestasi belajar matematika siswa dengan model pembelajaran langsung adalah dalam pembelajaran Jigsaw II setiap siswa dalam satu kelompok semuanya aktif dalam penentuan tema dan 
pembagian kelompok. Siswa aktif dalam proses pembelajaran dan bias mengerjakan tugas dengan baik. Sedang pembelajaran langsung siswa cenderung pasif dan tingkat pemahaman rendah karena pembelajaran didominasi oleh guru. Dari uraian tersebut dapat disimpulkan bahwa prestasi belajar matematika siswa yang diberikan model pembelajaran Jigsaw II lebih baik daripada model pembelajaran langsung.

$H_{O B}$ diterima, hal ini berarti bahwa pada keempat tipe kepribadian (melankolis, koleris, phlegmatis dan sanguinis) mempunyai prestasi belajar yang sama. Dengan demikian hipotesis kedua tidak didukung data. Hasil penelitian ini sejalan dengan penelitian yang dilakukan Taufik Hidayat (2013) yang menyimpulkan tidak ada perbedaan pengaruh kepribadian koleris, melankolis, phlegmatis dan sanguinis terhadap prestasi belajar.

Faktor yang menyebabkan siswa dengan tipe kepribadian melankolis, koleris, phlegmatis, dan sanguinis mempunyai prestasi belajar yang sama karena tes yang terdiri dari 40 option dengan kalimat yang panjang, merupakan tes kepribadian secara umum yang diambil dari buku "Personality Plus", kemungkinan kurang sesuai untuk menentukan tipe kepribadian siswa SMK. Selain itu soal tes prestasi belajar matematika dibuat oleh orang yang belum banyak pengalaman materi Barisan dan Deret Matematika SMK, sehingga kemungkinan soal tes prestasi kurang memenuhi atau kurang terstandar dalam menentukan prestasi belajar matematika siswa SMK.

$H_{O A B}$ diterima, hal ini menunjukkan bahwa tidak terdapat interaksi antara model pembelajaran dan tipe kepribadian terhadap prestasi belajar matematika siswa. Hasil penelitian ini sesuai dengan penelitian yang dilakukan oleh Taufik Hidayat (2013) yang menyatakan bahwa tidak ada interaksi antara model pembelajaran dan kepribadian siswa terhadap prestasi belajar matematika siswa pada materi aritmatika sosial. Hal ini berarti perbandingan sel antar baris dalam satu kolom dan perbandingan sel antar kolom dalam satu baris mengikuti perlakuan yang ada pada model pembelajaran dan tipe kepribadian.

Dengan memperhatikan efek baris (model pembelajaran) maka pada masing-masing tipe kepribadian melankolis, koleris, phlegmatis dan sanguinis prestasi belajar matematika siswa pada materi barisan dan deret dengan menggunakan model pembelajaran Jigsaw II lebih baik daripada model pembelajan langsung.

Faktor yang menyebabkan tidak adanya perbedaan prestasi belajar matematika siswa dengan tipe kepribadian melankolis, koleris, phlegmatis dan sanguinis baik pada model pembelajaran Jigsaw II maupun langsung karena:

a. Pada umumnya, seluruh siswa mempunyai kemampuan yang sama dalam menyelesaikan soal barisan dan deret matematika. Hal ini dikarenakan materi barisan dan deret matematika sudah pernah dipelajari di SMP. Kenyataan bahwa cara mengerjakan soal barisan dan deret matematika adalah sama, menyebabkan adanya keseragaman pemahaman siswa. Artinya, meskipun siswa 
memiliki tipe kepribadian yang berbeda, namun mereka memiliki kemampuan yang sama dalam menyelesaikan soal barisan dan deret matematika.

b. Dalam proses menyelesaikan soal-soal barisan dan deret, siswa pada umumnya melihat contoh soal atau soal-soal yang telah diberikan sebelumnya, sehingga jika diberikan soal yang tidak sesuai dengan contoh soal atau soal-soal sebelumnya maka siswa merasa kesulitan dalam menyelesaikannya, baik pada siswa dengan pembelajaran kooperatif tipe Jigsaw II maupun langsung.

c. Pembelajaran kooperatif mengajak siswa untuk bekerjasama dalam memecahkan masalah. Dalam setiap kesempatan pembelajaran, siswa yang pandai memberikan bantuan pada siswa yang merasa kesulitan. Hal ini diduga menjadikan siswa dengan masing-masing kepribadian memiliki prestasi belajar yang sama.

\section{SIMPULAN DAN SARAN}

Berdasarkan hasil penelitian dan analisis data yang telah dilakukan diperoleh simpulan sebagai berikut: 1) Prestasi belajar matematika siswa yang mendapat pembelajaran dengan model kooperatif tipe Jigsaw II lebih baik daripada model pembelajaran langsung, 2) Siswa dengan tipe kepribadian melankolis, koleris, phlegmatis dan sanguinis memiliki prestasi belajar matematika yang sama, 3) Pada masing-masing tipe kepribadian (melankolis, koleris, phlegmatis dan sanguinis), prestasi belajar matematika siswa yang mendapat pembelajaran dengan model kooperatif tipe Jigsaw II lebih baik daripada model pembelajaran langsung, 4) Pada masing-masing kategori model pembelajaran (Jigsaw II maupun model pembelajaran langsung), siswa dengan tipe kepribadian melankolis, koleris, phlegmatis dan sanguinis memiliki prestasi belajar matematika yang sama.

Berdasarkan kesimpulan yang telah disampaikan tersebut, ada beberapa hal yang perlu diperhatikan oleh guru agar prestasi belajar matematika dapat ditingkatkan, antara lain: 1) Dalam melaksanakan kegiatan pembelajaran matematika pada materi barisan dan deret, hendaknya guru dalam proses pembelajarannya menggunakan model pembelajaran kooperatif tipe Jigsaw II, 2) Guru hendaknya mengadakan persiapan sebaik mungkin, agar proses pembelajarannya dapat berlangsung dengan lancar sesuai dengan tujuan yang diharapkan.

\section{Daftar Pustaka}

Ariadi Wijaya. 2012. Pendidikan Matematika Realistik, (Suatu Alternatif Pendekatan Pembelajaran Matematika). Yogyakarta. Graha Ilmu.

Karaoglan, D. 2009. The Relationship Between $6^{\text {th }}$ Grade Student's Problem Solving Achievement And Mathematics Achievement Scores After Compleshing Instruction on Problem Solving.Thesis The Department of Elementary Science and Mathematics Education: Middle East Technical University Turkey. 
Litteauer, F. 2011. Personality Plus (Kepribadian Plus).Tangerang: Karisma.

Miftahul Huda. 2013. Cooperative Learning.Yogyakarta: Pustaka Pelajar.

OECD. 2014. PISA 2012 Result in Focus: What 150-Year-OldsKnowand What They Can Dowith What They Know. http://www.oecd.org/pisa/ keyfindings/pisa-2012-results-overview.pdf. Diunduh tanggal 26 Januari 2015.

Pimta,S, Tayruakham, S and Nuangchalem, P. 2009. "Factors Influencing Mathematic ProblemSolving Ability of Sixth Grade Students”. Journal of Social Sciences, Vol. 5(4), pp 381385. ISSN 1549-3652.

Rivera, DP . 1996. "Using Cooperative Learning to Teach Mathematics to student with Learning Disabilities." $L D$ Forun, Vol. 21 n3 pp 23-33. www.ldonline.org /ld_indepth/math_skills/coopmath.html. Diunduh tanggal 22 Januari 2013.

Taufik Hidayat. 2013. Eksperimentasi Pembelajaran Matematika dengan Model Pembelajaran Kooperatif Jigsaw II dan Think-Pair-Share (TPS)Ditinjau Dari Tipe Kepribadian Siswa kelas VII SMP Negeri di Kabupaten Pacitan.Tesis.PPs:UNS Surakarta.

Zakaria and Zanaton. 2007. "Promoting cooperative learning in science and mathematics Education". Eurasia Journal of Mathematics, Science \& Technology Education. 3(1), 35-39. www.ejmste.com. Diunduh tanggal 28 Januari 2013. 